ANKAD E-ISSN:2587-0491

\author{
Araştırma Makalesi/Research Article
}

\title{
Ortaokul Kaynaştirma Öğrencilerinin Sosyal Bilgiler Dersi Hakkindaki Görüşleri
}

\section{Serpil DEMIREZEN ID 1}

Fatma Beyza AÇIL id 2

${ }^{1}$ Dr. Öğr. Üyesi, Akdeniz Üniversitesi Eğitim Fakültesi Sosyal Bilgiler Eğitimi ABD., e-mail:

serpil.demirezen@gmail.com

${ }^{2}$ Yüksek Lisans Öğrencisi, Akdeniz Üniversitesi Eğitim Bilimleri Enstitüsü Sosyal Bilgiler Eğitimi Bilim Dalı, e-mail: beyzaac196@gmail.com

Anahtar Kelimeler

Sosyal bilgiler, kaynaştirma eğitimi, kaynaştırma öğrencileri, olgubilim

\section{Keywords}

Social studies, inclusive education, inclusion students, phenomenology

\section{Sorumlu yazar/Corresponding Author}

Serpil Demirezen, Dr. Öğr. Üyesi, Akdeniz

Üniversitesi Eğitim Fakültesi Sosyal

Bilgiler Eğitimi ABD

e-mail: serpil.demirezen@gmail.com

Geliş/Received: 23.07 .2020

Kabul/Accepted: 01.10 .2020

\section{$\ddot{O} \mathbf{z}$}

Bu çalışmanın amacı, ortaokul seviyesinde örgün eğitime devam eden kaynaştırma öğrencilerinin sosyal bilgiler dersine yönelik görüşlerini ortaya koymak ve özel gereksinimli öğrenciler için sınıf içi uygulamalar yapan sosyal bilgiler öğretmenlerine öğrenci algıları ile yol gösterebilmektir. Araştırmada nitel araştırma yönteminden, olgu bilim (fenomenoloji) modeli kullanılmıştır. Araştırmanın çalışma grubunu Antalya il merkezindeki 3 ortaokulda öğrenim gören 15 özel gereksinimli öğrenci oluşturmuştur. Yüz yüze görüşmeler yapılarak toplanan araştırma verileri betimsel analiz kullanılarak analiz edilmiştir. Araştırmanın sonucunda kaynaştırma öğrencilerinin sosyal bilgiler dersine, öğretmene, sosyal bilgiler öğretmenine yönelik olumlu metaforlar geliştirdikleri; sosyal bilgiler dersini sevdikleri ve sosyal bilgiler dersinin konularını söyleyebildikleri görülmüştür. Ayrıca sosyal bilgiler dersinin öğretmen merkezli işlendiği ve daha fazla aktif öğrenmeye yönelik işlenmesi yönünde bulgular saptanmıştır. $\mathrm{Bu}$ sonuçlar 1şığında çalışma grubundaki kaynaştırma öğrencilerinin sosyal bilgiler dersine yönelik olumlu görüşlerinin olduğu ve dersin işlenişine yönelik önerileri tespit edilmiştir. Araştırma sonuşları doğrultusunda kaynaştırma öğrencileri için sosyal bilgiler dersinde sınıf ortamının ve dersin işılenişinin onların ihtiyaçları doğrultusunda düzenlenmesi önerileribilir.

\section{Önerilen Atıf / Suggested Citation:}

Demirezen, S. \& Açıl, F. B. (2020). Ortaokul Kaynaştırma Öğrencilerinin Sosyal Bilgiler Dersi Hakkındaki Görüşleri, Anadolu Kültürel Araştırmalar Dergisi, 4(3), 278-294 


\title{
Secondary School Inclusion Students' Views on the Social Studies Course
}

\begin{abstract}
This study aimed to explore the views of secondary school inclusion students who receive formal education on the social studies course and to guide social studies teachers who practice classroom activities for special needs students through student perceptions. The study used a phenomenological research design. The sample consisted of 15 students with special needs who were attending three secondary schools in the city centre of Antalya. The data were collected through face-to-face interviews were analysed using descriptive analysis. According to the analysis results, the inclusion students developed positive metaphors for the social studies course, teacher, and social studies teacher. The analysis results also showed that the inclusion students enjoyed the social studies course and could tell the topics of social studies topics. Additionally, there were findings that the social studies course is teacher-centred and should be more focused on active learning. Accordingly, the study found that the participating inclusions students had positive views on the social studies course and expressed their demands for the delivery of the course. Based on the results, it may be suggested to organise the classroom environment in the social studies course and the delivery of the course in line with the needs of inclusion students.
\end{abstract}

\section{GíRiş}

Okullar, belirli planlar ve programlar çerçevesinde eğitim öğretim faaliyetlerini sürdürmenin yanında bireyin toplumsallaşma sürecine katkıda bulunan önemli kurumlardır. Bireyin akademik yönden gelişimini sağlamakla birlikte sosyal becerilerin de kazandırıldı̆̆ normal gelişim gösteren öğrencilerin yanı sıra özel eğitime ihtiyaç duyan öğrenciler için de bir eğitim yuvasıdır. Okullarda farklı gelişim özelliklerine sahip özel gereksinimli öğrencilerin, akranları ile birlikte eğitim öğretim ihtiyaçlarının karşılanabilmesi için kaynaştırma eğitimi uygulanmaktadir.

Kaynaştırma eğitimi, MEB Özel Eğitim Hizmetleri Yönetmeliği (2018)’nde “özel bir eğitime ihtiyacı olan bireylerin her kademede normal akranlarıla birlikte etkileşim içerisinde bulunarak eğitimlerini en üst düzeyde karşılayabilmek amacıyla verilen eğitim" olarak tanımlanmıştır. Kaynaştırma kavramı; genel bir sınıfta bulunan özel gereksinimli öğrencilerin eğitimlerinin, özel eğitim desteği ile birlikte genel sınıflarda sürdürülmesini ifade etmektedir (Kargın, 2004). Kaynaştırma eğitiminin hedef kitlesi olan özel gereksinimli birey kavramı ise aynı yönetmelikte "bireysel ve gelişim özellikleri ile eğitim yeterlilikleri açısından akranlarından anlamlı düzeyde farklılık gösteren birey" olarak tanımlanmaktadır (MEB Özel Eğitim Hizmetleri Yönetmeliği, 2018).

Dünya Sağlı Örgütü’nün yayımladığı Dünya Engellilik Raporu verilerine göre Dünya nüfusunun \%15'i (yaklaşık 1 milyar insan) özel eğitime ihtiyaç duymaktadır. Aynı raporda Dünya genelinde çeşitli engellilik sorunları yaşayan çocukların okula başlama oranlarının engelli olmayan akranlarına göre daha düşük olduğu ve bu durumun yoksul ülkelerde daha belirgin olsa da dünyanın her bölgesinde görüldüğü belirtilmektedir (WHO, 2011). Türkiye'de ise TÜIK (2011) verilerine göre nüfusun yaklaşık \%7'si özel gereksinime ihtiyaç duyarak yaşamaktadır. TÜİK (2010) tarafından yapılan bir diğer araştırmaya göre özel gereksinimli nüfusun \%41,6'sı okur-yazar değilken sadece \% 7,7'si lise ve daha üstü bir eğitim almaktatadır. $\mathrm{Bu}$ bilgilere bakıldığında özel gereksinimli bireylerin topluma kazandırılmasında eğitimin üstlenmesi gereken rolün oldukça önemli olduğu anlaşılmaktadır. Özel eğitime gereksinim duyan çocukların diğer öğrencilerle aynı öğretim ortamına dahil edilmesi, eşitsizliğin ortadan kaldırılmasına yardımcı olacaktır (WHO, 2011). Bu nedenle özel eğitime ihtiyaç duyan çocukları topluma kazandırmak amacıyla fiziksel, bilişsel ve sosyal becerilerine katkı sağlayacak eğitim ihtiyaçlarının karşılanması önemlidir (Diken ve Sucuoğlu, 1999). 
Özel eğitim, Türk Milli Eğitiminin genel amaçları ve ilkeleri doğrultusunda özel bir eğitime ihtiyacı olan bireylerin, kendi temel ihtiyaçlarını karşılayabilecek becerileri geliştirmeyi hedeflemektedir. Bununla birlikte toplum ile uyum sağlayabilen, çevresiyle iyi ilişkiler kuran, üretken ve mutlu bireyler olabilmeleri için kendi yetenekleri doğrultusunda gerek mesleğe gerekse yaşama hazırlanmalarını da amaçlamaktadır (MEB ÖRGM, 2010). Özel eğitime ihtiyaç duyan öğrenciler için yürütülen kaynaştırma uygulamaları öğrencilerin topluma katkıda bulunmalarını sağlayarak, öğrencinin öğrenme sürecini desteklemekte, arkadaşlarıyla olan ilişkilerini geliştirme noktasında ise bireysel farklılıkların kabulüyle birlikte bireyler arası eşitliği desteklemektedir. (Shapiro, 1999'dan Aktaran: Urban, 2013). Lewis ve Doorlog (1987) özel gereksinime ihtiyacı olan bireylerin topluma kazandırılmasında kaynaştırma eğitimin önemini vurgulayarak kaynaştırma eğitimini, normal eğitim kurumlarında olmasını engelleyecek veya kurumlara uyumunu zorlaştıracak kadar ağır düzeyde engelli olmayan öğrencilerin, normal akranlarıyla birlikte eğitim kurumlarına yerleştirilmesine olanak sağlanması şeklinde ifade etmektedir.

Özel gereksinimli öğrencilerin eğitimlerini, normal gelişim gösteren akranlarıyla birlikte almaları, eğitimde fırsat eşitliği açısından oldukça önemlidir. $\mathrm{Bu}$ süreç, kaynaştırma uygulamaları ile düzenlenip yürütülmektedir. Kaynaştırma eğitimdeki amaç, özel gereksinimli öğrencinin akranları ile uyumunu sağlayarak eğitim ihtiyaçlarını karşılamak, onları hayata hazırlamak şeklinde özetlenebilir (Demirezen ve Akhan, 2016). Kaynaştırma uygulamaları sadece özel eğitim öğretmenlerinin görevi değil aynı zamanda tüm öğretmenlerin görevidir. Öğretmenler, gerek üniversitede lisans dersleri arasında aldıkları özel eğitim dersi ile gerekse hizmet içinde aldıkları eğitimlerle özel gereksinimli öğrencilerinin duygularını ve tutumlarını daha iyi anlayabilmektedir. Bu sayede de bu öğrencelerin olası kaygılarına daha iyi yanıt verebileceklerdir (Bayar ve Üstün, 2017'den Aktaran: Akhan ve Ateş, 2019). Öğretmenler sınıflarındaki kaynaştırma öğrencilerine karşı olumlu tavır sergilemelidir. Özel gereksinimli öğrencilerin de bireysel farklılıklara sahip olduğu bilinerek gerekli düzenlemelere gidilmeli hatta verilen eğitim öğrencilerin kendi ilgi alanlarının gelişmesine yardımcı olmalıdır (Kaya, 2014). Öğretmenler özel gereksinimli öğrencinin, eğitsel ve sosyal gelişimini izlemeli; okul yönetimi, öğrencinin ailesi, rehberlik servisi ve destek personellerle iş birliği içerisinde öğretim sürecini planlamalıdır. Öğrenicinin ihtiyacına uyum sağlayabilmek için uygun yöntem ve teknikleri uygulamalıdır (MEB ÖRGM, 2013). Öğretmenler, kaynaştırma uygulamaları kapsamında öğrencilerin özel eğitim ihtiyaçlarına uygun olan Bireyselleştirilmiş Eğitim Programı (BEP) uygulamakla yükümlüdürler. Okullarda yürütülen kaynaştırma uygulamaları, akranlarından farklı gelişim gösteren öğrencilerin bireysel farklılıklarına uygun olarak planlanmalı ve sürdürülmelidir. Her bir kaynaştırma öğrencisinin sahip olduğu gelişim özellikleri kendine özgüdür. Bu öğrencilerin bireysel farklılıklarının hem öğretmenleri hem de akranları tarafindan doğru anlaşılması, onların gelişimleri açısından oldukça önemlidir.

Sosyal bilgiler dersi bireysel farklılıkların tanınmasında rehber ders görevini üstlenmektedir. $\mathrm{Bu}$ sayede sosyal bilgiler toplumun ilerlemesine, insanlığın uyum içerisinde yaşamasına yardımcı olur. Ayrıca özel gereksinimli öğrencilerin de toplum ile uyum sağlamalarında, sınıf arkadaşlarıyla kaynaştırılması konusunda, kendi ilgi alanlarını tanımasında, sınıf arkadaşlarıyla ortak bir yolda buluşturulmasını sağlayabilir. (Garcia ve Michaelis, 1988). Sosyal bilgiler eğitiminin bireysel farklılıklara sahip öğrenciler için önemini vurgulayan Troy ve Busby (2015) demokratik bir toplumda aktif vatandaşlar yetiştirmeyi hedefleyen sosyal bilgiler dersini kaynaştırma öğrencileri için normal öğrenciler ile birlikte aynı fırsata sahip olarak; bilgi, beceri ve tutumlarını geliştirmeye yönelik olması gerektiğini belirtmektedir. Ochoa ve Shuster (1980) ise sosyal bilgilerin öncelikli amacının toplumların, milletlerin ve dünyanın refahında sorumluluk sahibi vatandaşların yetiştirilmesi şeklide belirtmiştir. 
Sosyal bilgiler öğretimi bireye yerel ve küresel toplumun tarihini, ekonomisini, coğrafyasını, hukukunu, felsefesini, antropolojisini ve sosyolojisi gibi sosyal bilimleri kapsayan disiplinleri kazandırmayı amaçlamaktadır. Bu ders sayesinde birey ileriki yaşamında topluma karşı aidiyet duygusunu geliştirebilmektedir. Bu kapsamda hem normal öğrencilerin hem de özel gereksinimli öğrencilerin bu yeterliliğe ulaşması ve sosyalleşmesi beklenir (Akhan ve Sönmez, 2018). Sosyal bilgiler öğretmenlerine, özel gereksinimli öğrencilerin eğitimi için fikir verdiği çalışmasında McFarland (1998) öğretmenin öncelikli görevinin öğrenciyi doğru bir şekilde anlayıp öğrenciye yol göstermek ve toplum içerisinde onları yönlendirmek olduğunu belirtmiştir. Belki öğrenci, sosyal bilgiler dersi ile ilgili hiçbir konuyu hatırlayamayacak ama ona yol gösteren öğretmenini mutlaka hatırlayacaktır. Bu doğrultuda Akhan ve Ateş (2019) ortaokul kademesinde, bireysel farklılıkları kabul eden, birbirlerine karşı sayg1 gösteren, sosyalleşmelerine katkı sağlayacak sosyal bilgiler öğretmenlerine önemli görev düştüğünü belirtmiştir.

Literatürde sosyal bilgiler dersi ve kaynaştırma eğitimi odaklı çalışmalar incelendiğinde ağırlıklı olarak sosyal bilgiler öğretmenlerinin ve öğretmen adaylarının kaynaştırma eğitimine yönelik yeterliliklerini ve görüşlerini ortaya koymayı amaçlayan çalışmalara rastlanmaktadır. Yaylacı ve Aksoy (2016), sosyal bilgiler öğretmenlerinin kaynaştırma eğitimini destekledikleri; fakat kaynaştırma eğitimi konusunda kendilerini yeterli görmedikleri sonucuna ulaşmışlardır. Benzer şekilde İlk ve Açıkalın (2018) da araştırmaları sonucunda sosyal bilgiler ögretmenlerinin uygulamalarda kendilerini yeterli hissetmedikleri, sosyal bilgiler dersinde kaynaştırma uygulamalarını çok yetersiz buldukları ve çözüm olarak ayrıştırmayı önerdikleri görülmektedir. Akhan ve Sönmez (2018) sosyal bilgiler öğretmenlerinin özel eğitim öğrencilerine yönelik özel alan yeterliliklerini inceledikleri çalışmada sosyal bilgiler öğretmenlerinin özel eğitim öğrencilerine yönelik sınırlı- orta düzey yeterlilik düzeyinde oldukları sonucuna ulaşmışlardır. Demirezen ve Akhan (2016) çalışmalarında sosyal bilgiler öğretmenlerinin kaynaştırma uygulamalarının öneminin farkında olmalarına karşın, bu konuda istedikleri düzeyde performans sergileyemediklerini belirttiklerini ortaya koymuşlardır. Yıldırım (2019)'da araştırmasında sosyal bilgiler öğretmenlerinin kaynaştırma eğitimini destekleyici bir tutuma sahip oldukları ancak bu eğitim modelinde kendilerini yeterli görmedikleri sonucuna ulaşmıştır. Akhan ve Ateş' in (2019) sosyal bilgiler öğretmen adaylarının kaynaştırma eğitimine yönelik öz yeterlilik inançlarını inceledikleri araştırmada ise öğretmen adaylarının kaynaştırma yeterlilik düzeylerinin ve öğretmen öz yeterlik düzeylerinin orta düzey olduğu tespit edilmiştir. Sharma, Forlin ve Loreman (2008) tarafından öğetmen adaylarının kaynaştırmaya yönelik tutumlarını inceleyen geniş kapsamlı bir çalışma yapılmıştır. kaynaştırma uygulamaları hakkında verilen eğitimin öğretmen adaylarının kaynaştırmaya yönelik tutumları, engelli kişilerle ilgili duyguları ve kaynaştırma konusundaki endişeleri üzerindeki etkilerini belirlemeyi amaçlayan çalışmaya Avustralya, Kanada, Hong Kong ve Singapur'dan 603 öğretmen adayı katılmıştır. Araştırma sonucunda, öğretmen adaylarına kaynaştırma uygulamaları hakkında verilen eğitim ile öğretmen adayları çeşitli engellilik koşullarını daha iyi anlamış, kaynaştırma ile ilgili mevzuatı kavramış ve engelliö ğrencileri sınıflarına-derslerine dahil etme hususunda daha istekli hale gelmişlerdir.

Litaratürde kaynaştırma öğrencilerinin sosyal bilgiler dersine yönelik görüşlerini ve sosyal bilgiler dersindeki performanslarını ele alan çalışmalar da yer almaktadır. Topçu ve Katılmış (2013) yarı zamanlı kaynaştırma öğrencilerinin sosyal bilgiler dersine yönelik görüşlerini inceledikleri çalışmada öğrencilerin derse karşı olumlu tutumlarının olduğunu belirtmişlerdir. Büyükalan ve Yaylacı (2018) kaynaştırma öğencilerinin sosyal bilgiler dersine yönelik metaforlarını incedikleri çalışmada öğrencilerin, "sosyal yaşamı içeren ve yol gösterici" gibi olumlu görüşler belirttikleri sonucunu ortaya koymuşlardır. Yaşar ve Bayır (2010) normal 
gelişim gösteren 5. sınıf öğrencilerinin sosyal bilgiler dersi metaforlarına bakıldığında "bilgisayar, dünya, hayat ve tarih" imgelerini kullandıklarını belirtmişlerdir. Görmez (2016) kaynaştirma öğrencilerinin sosyal bilgiler dersindeki performans düzeylerini gözlem tekniği ile incelediği çalışmada Bireyselleştirilmiş Eğitim Programında (BEP) öğrencinin olması gereken düzey ile öğrencinin mevcut düzeyi arasında çok ciddi bir farkın olduğu, kaynaştırma öğrencilerinin genelinin basit direktifleri ve kavramları (kendini tanıtma, çevresi hakkında bilgi verme gibi) anladıkları ama soyut kavramları ve uzun cümleleri (demokrasi, tarih, vatandaş, iklim vb.) anlamadıkları, dersten çabuk sıkıldıkları, kendilerine yöneltilen sorulara anlamsız cevaplar verdikleri ya da hiç cevap veremedikleri sonuçlarına ulaşmıştır. Young Buckley (2005) sosyal bilgiler kaynaştırma sınıflarında normal ve özel eğitim öğretmenleri arasında işbirlikçi ilişkilerin kurulması ve sürdürülmesine yönelik çalışmasında görüşme, gözlem ve BEP'leri inceleyerek veri toplamıştır. Araştırma sonunda özel eğitim öğretmeni olan olmayan öğretmenler arasında işbirliği sağlanmasının gerekli olduğu, en büyük sorun olarak zaman eksikliğinin görüldüğü ve BEP'lerin yeterli olmadığ 1 tespit edilmiştir. Berkeley, Marshak, Mastropieri ve Scruggs (2011) tarafından yapılan çalışmada ortaokul kaynaştırma sınıflarında sosyal bilgiler metinlerinin anlaşılması için kendi kendine sorgulama stratejisinin etkisini ortya koymak amaçlanmıştır. Yapılan deneysel çalışma sonucunda stratejinin uygulandığı deney grubundaki öğrencilerin sosyal bilgiler metinlerini okumada, metinlerle ilgili çoktan seçmeli ve açık uçlu testlerde kontrol grubundaki öğrencilere göre daha iyi performans gösterdikleri belirlenmiştir.

Literatür incelendiğinde kaynaştırma öğrencilerinin sosyal bilgiler dersine yönelik algılarını ortaya koyan çalışmaların sınırlı olduğu görülmektedir. Kaynaştırma uygulamalarının sosyal bilgiler dersi kapsamında etkili şekilde uygulanabilmesi için kaynaştırma öğrencilerinin dersten beklentilerinin açık bir şekilde ortaya konması gerekmektedir. Bunun yanı sıra sosyal bilgiler dersinin bireysel farklılıkların önemini vurgulayarak özel gereksinimli öğrencilerin toplumsallaşmaları sürecinde en etkli ders olduğunu söylemek mümkündür. Bu doğrultuda bu araştırmanın amacı; ortaokul düzeyinde eğitim gören kaynaştırma öğrencilerinin sosyal bilgiler dersine yönelik görüşlerini ortaya koymak ve özel gereksinimli öğrenciler için sınıf içi uygulamalar yapan sosyal bilgiler öğretmenlerine öğrenci algıları ile yol gösterebilmektir. Bu amaç doğrultusunda aşağıdaki sorulara yanıt aranmıştır.

1. Kaynaştırma öğrencilerinin sosyal bilgiler dersine, öğretmenlere ve sosyal bilgiler öğretmenlerine yönelik metaforları nasıldır ve bu metaforların sebepleri nelerdir?

2. Kaynaştırma öğrencilerinin sosyal bilgiler dersi ile bağdaşlaştırdıkları konular nelerdir?

3. Kaynaştırma öğrencileri sosyal bilgiler dersinin işlenişine yönelik görüşleri nelerdir?

4. Kaynaştırma öğrencileri sosyal bilgiler dersinin işlenişine yönelik önerileri nelerdir? Kaynaştırma öğrencilerinin sosyal bilgiler dersi hakkındaki görüşlerinin incelendiği bu çalışma, sürecin öğrencilerin gözünden değerlendirilmesi ve kaynaştırma uygulamalarına bir dönüt niteliği taşıyarak literatüre katkı sağlaması bakımından önemlidir.

\section{YÖNTEM}

$\mathrm{Bu}$ araştırmada nitel araştırma yönteminden, olgu bilim (fenomenoloji) modeli kullanılmıştır. Olgular yaşadığımız dünyada olaylar, tecrübeler, algılar, tutumlar, kavramlar ve durumlar gibi çeşitli şekillerde karşımıza çıkabilmektedir. Bu olgularla günlük yaşantımızda çeşitli şekillerde karşılaşabiliriz. Ancak bu tanışıklık, olguları tam olarak anladığımız anlamına gelmez. Bize tamamen yabancı olmayan aynı zamanda da tam anlamını kavrayamadı̆̆ımız olguları araştırmayı amaçlayan çalışmalar için olgu bilim uygun bir araştırma zemini oluşturur. Bireylerin düşüncelerinin altında yatan anlamları ortaya çıkarmak amacıyla olgu bilim araştırma deseni kullanılır (Yıldırım ve Şimşek, 2006). Bu çalışmada da özel gereksinimli 
öğrencilerin sosyal bilgiler dersine ilşkin görüşlerini anlamlandırabilmek amacıyla olgu bilim deseni kullanılmıştır.

\section{1. Çalışma Grubu}

Bu araştırmanın çalışma grubunu 2018-2019 eğitim öğretim yılında Antalya il merkezindeki 3 ortaokulda öğrenim gören 15 özel gereksinimli öğrenci oluşturmuştur. Çalışma grubu kolay ulaşılabilir durum örneklemesi kullanılarak oluşturulmuştur. Çalışma grubunun kolay ulaşılabilir olması, araştırmacının hız ve pratiklik açısından yakın ve erişimi kolay olan durumu seçmesidir (Yıldım ve Şimşek, 2006). Çalışma grubunda yer alan öğrencilerin BEP'lerinde yer alan engel durumlarına göre dağılımları Tablo 1'de yer almaktadır.

Tablo 1. Çalışma Grubunda Yer alan Öğrencilerin Engel Durumları

\begin{tabular}{ll}
\hline Engel Durumları & f \\
\hline Görme Engeli & 6 \\
\hline Öğrenme Güçlüğü & 4 \\
\hline Dikkat Eksikliği & 3 \\
\hline Bedensel Yetersizlik & 2 \\
\hline Toplam & 15 \\
\hline
\end{tabular}

\subsection{Verilerin Toplanması ve Analizi}

$\mathrm{Bu}$ araştırmanın verileri, yüz yüze görüşme tekniği ile toplanmıştır. Çalışma grubunun sosyal bilgiler dersine yönelik görüşlerinin belirlenmesi amacıyla önceden belirlenmiş yarı yapılandırılmış görüşme ve metafor soruları sorulmuştur. İlk dört soru metafor şeklinde son üç soru ise açık uçlu sorulardan oluşmaktadır. Çalışma grubundaki öğrencilere metafor olarak, "sosyal bilgiler....... gibidir/ benzer, çünkü.......", "öğretmen....... gibidir/ benzer, çünkü.......", "sosyal bilgiler öğretmeni....... gibidir/ benzer, çünkü.......", "sosyal bilgiler dersinin konuları....... gibidir/ benzer, çünkü......." açık uçlu sorular olarak; sosyal bilgiler dersi, sosyal bilgiler dersinin nasıl işlendiği ve sosyal bilgiler dersinin nasıl işlenmesi gerektiği ile ilgili sorularak görüşleri alınmıştır. Araştırmaya katılan öğrencilerin, yapılan benzetmelere mantıklı bir açıklama getirmeleri için "çünkü....." ifadesine yer verilmiştir. Bu benzetmenin akıllarına gelebilecek herhangi bir şey olabileceği belirtilmiştir. Ayrıca katılımcıların görüşlerinin daha derinlemesine alınması için açık uçlu sorulara da yer verilmiştir.

Araştırmada elde edilen veriler betimsel analiz kullanılarak analiz edilmiştir. Betimsel analiz, verilen bir durumu tam ve dikkatli bir şekilde açıklar. Betimsel analizde ulaştığımız sonuçlar önceden seçilen temalara göre özetlenip yorumlanır. Analizde görüşülen ye ya gözlemlenen kişilerin etkili bir şekilde görüşlerini yansıtmak için doğrudan alıntılara sık sık yer verilir. Betimsel analizin amacı, elde ettiğimiz verileri düzenlenmiş ve yorumlanmış bir şekilde okuyucunun karşına çıkarmaktır. Bu amaçla elde edilen veriler sistematik ve açık bir şekilde betimlenir. Daha sonra yapılan bu betimlemeler yorumlanır. (Yıldırım ve Şimşek, 2006).

Araştırmada elde edilen verilerin analizinde öğrencilerin cevaplarından doğrudan alıntılar yapılmıştır Yıldırım ve Şimşek (2006) betimsel analizin kullanıldığ1 araştırmalarda görüşülen kişilerden doğrudan alıntılara yer verilmesinin ve bunlara dayalı sonuçlara ulaşılmasının geçerlik için önemli olduğunu belirtmişlerdir. Doğrudan alıntılarda çalışma grubundaki her öğrenciye bir numara verilmiş ve alıntı yapılan öğrenci Ö1, Ö2, Ö3 ... şeklinde gösterilmiştir. 
Ayrıca araştırmada elde edilen verilerden uygun olanları, öğrenci cevaplarındaki sıklığı belirlemek amacıyla sayısallaştırılarak frekanslarla birlikte sunulmuştur.

Verilerin analizinde çalışmayı yürüten araştırmacı haricinde bir uzmandan da yardım alınmıştır. Öğrencilerin görüşme sorularına verdikleri cevaplar araştırmacılar tarafından ayrı ayrı analiz edilerek, görüş birliği ve görüş ayrılı̆̆ olan hususlar belirlenmiștir. Güvenirlik hesaplaması için Miles ve Huberman (1994) tarafından önerilen formül kullanılmıştır. Buna göre kodlamaların güvenirliği yüzde 85 olarak hesaplanmıştır. Güvenirlik hesaplamasının \%70'in üzerinde çıkması, araştırmalar için güvenilir kabul edilmektedir (Miles ve Huberman, 1994). Hesaplama sonunda elde edilen sonuç araştırma için güvenilir kabul edilmiştir.

\section{BULGULAR}

\subsection{Kaynaştırma Öğrencilerinin Sosyal Bilgiler Dersine, Öğretmenlere ve Sosyal} Bilgiler Öğretmenlerine Yönelik Metaforları ile Bu Metaforların Sebeplerine İlișkin Bulgular

Çalışma grubunda yer alan kaynaştırma öğrencilerinin, araştırmanın birinci alt problemini kapsayan görüşme sorularına verdikleri cevaplar ayrı ayrı analiz edilerek tablolaştırılmış ve açıklanan bulgulara aşağıda yer verilmiştir.

\section{1.a Kaynaştırma öğrencilerinin sosyal bilgiler dersi metaforlarına ilişkin bulgular}

Tablo 2. Kaynaştırma Öğrencilerinin Sosyal Bilgiler Dersine İlişkin Metaforları

\begin{tabular}{ll}
\hline Sosyal bilgiler metaforları & $\mathbf{f}$ \\
\hline Hayat & 4 \\
\hline Hiçbir şey & 2 \\
\hline Tarih & 2 \\
\hline Atatürk & 1 \\
\hline Savaş & 1 \\
\hline İlaç & 1 \\
\hline Orman & 1 \\
\hline Araba & 1 \\
\hline Coğrafya & 1 \\
\hline Güzellik & 1 \\
\hline
\end{tabular}

Tablo 2'ye göre kaynaştırma öğrencilerinin sosyal bilgiler dersine yönelik metaforları incelendiğinde, genel olarak sosyal bilgiler dersine yönelik olumlu metaforlar geliştirdikleri görülmektedir. Öğrencilerden sadece ikisi hiçbirşey çevabı vermişlerdir. Öğrencilerinin cevaplarından bazıları şu şekildedir:

Sosyal bilgiler dersini Atatürk'e benzetiyorum. Çünkü Atatürk'ü seviyorum. (Ö1).

Sosyal bilgiler dersini hiçbir şeye benzetemiyorum. Çünkü sınıf çok sesli ve ögretmenimiz bize bă̆ırıyor. (Ö2).

Ilaca benzetiyorum. Çünkü sosyal bilgiler dersi bana iyi geliyor. (Ö5).

Tarihe benzetiyorum. Çünkü tarih hakkında bilgi veriyor. (Ö11). 
Ormana benzetiyorum. Çünkü orman havası insana iyi gelir, bana da sosyal bilgiler dersi iyi geliyor. (Ö8).

Tablo 3. Kaynaştırma Öğrencilerinin Sosyal Bilgiler Metaforlarının Sebepleri

\begin{tabular}{lc}
\hline Sosyal Bilgiler Metaforlarının Sebepleri & $\mathbf{f}$ \\
\hline Hayattan örnek vermesi & 3 \\
\hline Tarihi öğretmesi & 3 \\
\hline Dersin iyi gelmesi & 3 \\
\hline Normal bir ders & 2 \\
\hline Atatürk'ü sevmek & 1 \\
\hline Öğretmenin bağırması & 1 \\
\hline Gürültülü sınıf & 1 \\
\hline Güzel konular & 1 \\
\hline Araba sürmek & 1 \\
\hline Farklı dersleri içermesi & 1 \\
\hline
\end{tabular}

Tablo 3'te kaynaştırma öğrencilerinin sosyal bilgiler dersine yönelik metaforlarının sebepleri incelendiğinde, öğrencilerin sosyal bilgilere yönelik olumlu yönde geliştirdikleri metaforların sebeplerinin de metaforlarını destekler yönde olumlu olduğu görülmektedir. Sosyal bilgiler dersini hiçbirşeye benzetemeyen iki öğrencinin "öğretmenin bağırması ve gürültülü bir sınıf" açıklaması yaptıkları görülmüştür. Öğrencilerin cevaplarından bazıları şu şekildedir:

Hayata benzer, hayattan örnekler veriyor. (Ö3).

Tarihe benzer, çünkü tarihimizi öğreniyoruz. (Ö6).

Hayat dersine benzer, çünkü eskiden yaşamış insanlardan ve medeniyetlerden bilgi verir. (Ö7).

Sosyal bilgiler dersini tarih dersine, coğrafya dersine benzetiyorum. Çünkü sosyal bilgiler dersi iki dersi de kaplyyor. (Ö15).

Hiçbir şeye benzetmiyorum çünkü derste sınıf çok gürültülü. (Ö13).

\section{1.b. Kaynaştırma öğrencilerinin öğretmen metaforlarına ilişkin bulgular}

Tablo 4. Kaynaştırma Öğrencilerinin Öğretmen Metaforları

\begin{tabular}{lc}
\hline Öğretmen metaforları & $\mathbf{f}$ \\
\hline Bilgi veren kişi & 4 \\
\hline İnsan & 3 \\
\hline Aile & 2 \\
\hline Canlı bomba & 1 \\
\hline Doğa & 1 \\
\hline
\end{tabular}




\begin{tabular}{ll}
\hline Hiç düşünmedim & 1 \\
\hline Cadılar & 1 \\
\hline Uçak & 1 \\
\hline İnsan & 1 \\
\hline Bilgili adam & 1 \\
\hline
\end{tabular}

Tablo 4'te çalışma grubundaki kaynaştırma öğrencilerinin öğretmen metaforlarının genel olarak somut varlıklar/kişiler şeklinde olduğu görülmektedir. İki öğrencinin, öğretmen kavramını "canlı bomba, cadılar" şeklinde olumsuz unsurlara benzettiği görülmektedir. Öğrencilerin cevaplarından bazıları şu şekildedir:

Öğretmen doğaya benzer çünkü, sürekli öğretmenimiz bize çevremizi temiz tutmamızı ister. (Ö2).

Hiç düşünmedim. (Ö3).

Cadılara benzer. Öğretmenleri sevmiyorum. (Ö5).

Iyi bir insana benzer. Çünkü hep iyi biri olmamızı istiyor. (Ö12).

Uçaklara benzer çünkü, beni derste düşündürüyor. (Ö8).

Tablo 5. Kaynaştırma Öğrencilerinin Öğretmen Metaforlarının Sebepleri

\begin{tabular}{ll}
\hline Öğretmen metaforları & f \\
\hline Öğretici & 5 \\
\hline İnsan & 3 \\
\hline Sinirli & 2 \\
\hline Sevmiyorum & 1 \\
\hline Düşündürücü & 1 \\
\hline İyileştirici & 1 \\
\hline Sevecen & 1 \\
\hline Fedakar & 1 \\
\hline Tablo 5’te calıma grubundaki kaynastrma ŏgrencilerinin ŏgretmenler için kulland
\end{tabular}

Tablo 5'te çalışma grubundaki kaynaştırma öğrencilerinin öğretmenler için kullandıkları metaforların sebepleri incelendiğinde, sevgi / fedakarlık / iyilik gibi değerlere odaklandıkları anlaşılmaktadır. Üç öğrencinin ise metaforlarındaki sebeplere yönelik "sinirli, sevmiyorum" açıklaması yaptığı görülmüştür. Kaynaştırma öğrencilerinin cevaplarından bazıları şu şekildedir:

Öğretmen canlı bombaya benzer çünkü, sinirleniyor. (Ö1).

Bilgili adama benzer. Çünkü çok şey öğretir. (Ö10).

Insana benzer çünkü normal bir insandır. (Ö11).

Bilgilendirici insana benzer çünkü konu anlatır. (Ö13). 


\section{1.c. Kaynaştırma öğrencilerinin sosyal bilgiler öğretmeni metaforlarına ilişkin bulgular}

Tablo 6. Kaynaştırma Öğrencilerinin Sosyal Bilgiler Öğretmeni Metaforları

\begin{tabular}{lc}
\hline Sosyal Bilgiler Öğretmeni Metaforları & f \\
\hline Bilgisayar & 2 \\
\hline Anne & 2 \\
\hline Hiçbir şey & 2 \\
\hline Tarım & 1 \\
\hline Melek & 1 \\
\hline Komedyen & 1 \\
\hline Arkadaş & 1 \\
\hline Kitap & 1 \\
\hline Cepheler & 1 \\
\hline Büyük Adam & 1 \\
\hline Üzüm & 1 \\
\hline Tarih & 1 \\
\hline Gezgin & 1 \\
\hline
\end{tabular}

Tablo 6'ya göre kaynaştırma öğrencilerinin sosyal bilgiler öğretmenine yönelik metaforları incelendiğinde öğrencilerin genel olarak sosyal bilgiler konularını çağrıştıran metaforlar ürettikleri görülmektedir. Bunun yanı sıra öğretmenin kişisel özelliğinden ya da öğrenciye yönelik tutumundan etkilenerek "anne / melek" gibi metaforlar üretildiği de görülmektedir. Öğrencilerinin cevaplarından bazıları şu şekildedir:

Sosyal Bilgiler ögrretmenleri anneme benzer. Çünkü ögretmen de bizi çok seviyor ve iyi davrantyor (Ö)1).

Sosyal Bilgiler ögretmenleri arkadaşa benzer. Çünkü öğretmen de arkadaş gibi sorunlarımızı dinler (Ö6).

Sosyal Bilgiler ögretmenleri tarihe benzer. Çünkü ögretmen sürekli eski konuları anlatıyor (Ö13).

Sosyal Bilgiler ögretmenleri bilgisayara benzer. Çünkü bize bütün bilgileri veriyor (Ö14).

Tablo 7. Kaynaştırma Öğrencilerinin Sosyal Bilgiler Öğretmeni Metaforlarının Sebepleri

\begin{tabular}{ll}
\hline Sosyal bilgiler ögretmeni metaforlarının sebepleri & $\mathrm{f}$ \\
\hline Bilgi vermesi & 5 \\
\hline Derslerde tarıma vurgu yapması & 3 \\
\hline Sorunlarla ilgilenmesi & 2 \\
\hline Derste güldürmesi & 1 \\
\hline
\end{tabular}




\begin{tabular}{ll}
\hline Uzun boylu olmasi & 1 \\
\hline Masal gibi olması & 1 \\
\hline Tarihten bahsetmesi & 1 \\
\hline Sürekli gezmesi & 1 \\
\hline
\end{tabular}

Tablo 7'de kaynaştırma öğrencilerinin, sosyal bilgiler öğretmenine yönelik metaforlarının sebeplerini açıklarken öğretmenin alan bilgisini aktarmasına yönelik ifadeler kullandıkları görülmektedir. Bunun yanı sıra öğretmenin öğrencilere yönelik tutumlarının ve kişisel özelliklerinin de öğrenciler için etkili bir husus olduğu anlaşılmaktadır.

Öğrencilerinin cevaplarından bazıları şu şekildedir:

Sosyal Bilgiler ögretmenleri komedyene benzer. Çünkü derste bizi çok güldürüyor (Ö5).

Sosyal Bilgiler ögrretmenleri tarihe benzer. Çünkü öğretmen sürekli tarımla ilgili konular işliyor. (Ö12).

Sosyal Bilgiler öğretmenleri gezginlere benzer. Çünkü bir tarihçi gibi her şeyi bilip bütün yerleri gezmişler. (Ö15).

\subsection{Kaynaştırma Öğrencilerinin Sosyal Bilgiler Dersi ile Bağdaştırdıkları Konulara}

\section{İlişkin Bulgular}

Tablo 8. Kaynaştırma Öğrencilerinin Sosyal Bilgiler Dersi ile Bağdaştırdıkları Konular

\begin{tabular}{ll}
\hline Sosyal bilgiler dersi ile bağdaştırılan konular & f \\
\hline Savaşlar & 3 \\
\hline Osmanlı Devleti & 2 \\
\hline Haklarımız & 2 \\
\hline Tarım & 2 \\
\hline Atatürk & 2 \\
\hline Kurtuluş Savaşı & 2 \\
\hline Sorumluklarımız & 1 \\
\hline Göç & 1 \\
\hline İklim & 1 \\
\hline Ormanlar & 1 \\
\hline Eski medeniyetler & 1 \\
\hline Doğal afetler & 1 \\
\hline Tarih konuları & 1 \\
\hline İpek Yolunda Türkler & 1 \\
\hline Yeryüzünde Yaşam & 1 \\
\hline Birey ve Toplum & 1 \\
\hline
\end{tabular}


Tablo 8'e göre çalışma grubundaki kaynaştırma öğrencilerin ağırlıklı olarak tarih konularını sosyal bilgiler dersi ile bağdaştırdıkları görülmektedir. Öğrencilerin cevaplarından bazıları şu şekildedir:

Aklıma Osmanlı Devleti, Atatürk geliyor. (Ö3).

Aklıma İpek Yolunda Türkler, Birey ve Toplum, Yeryüzünde Yaşam gibi ünite isimleri geliyor. (Ö15).

Sosyal Bilgiler dersi deyince aklıma Atatürk ve savaşlar geliyor. (Ö1).

Sosyal Bilgiler denilince aklıma Kurtuluş Savaşı, haklarımız ve sorumluluklarımız geliyor. (Ö14).

\subsection{Kaynaştırma Öğrencilerinin Sosyal Bilgiler Dersinin İşlenişine Yönelik Görüşlerine İlişkin Bulgular}

Tablo 9. Kaynaştırma Öğrencilerinin Sosyal Bilgiler Dersinin İşlenişine Yönelik Görüşleri

\begin{tabular}{lc}
\hline Görüşler & $\mathbf{f}$ \\
\hline Akıllı tahtadan & 9 \\
\hline Dersi öğretmen anlatır & 4 \\
\hline Ders kitabından anlatır & 3 \\
\hline Soru cevap şeklinde & 2 \\
\hline Oyun Oynayarak & 1 \\
\hline Kitap okuyarak & 1 \\
\hline Tahtaya yazarak & 1 \\
\hline
\end{tabular}

Tablo 9'a göre kaynaştırma öğrencilerinin sosyal bilgiler dersinin işlenişine ilişkin cevapları incelendiğinde, derslerde ağırlıklı olarak akıllı tahtanın ve ders kitabının kullanıldığı, dersin daha çok öğretmen merkezli yürütüldüğü anlaşılmaktadır. Öğrencilerin cevaplarından bazıları şu şekildedir:

Öğretmen akull tahtadan ve kitaplardan işliyor dersi (Ö2).

Öğretmen ders kitabını okutuyor, sorular soruyor, akıllı tahta kullanıyor (Ö3).

Öğretmen ders kitabı ve akıllı tahtadan dersi anlatır (Ö6).

Konular ders kitabından işleniyor. Öğretmen okuyor, soru soruyor ve tahtaya yazıyor (Ö7).

\subsection{Kaynaştırma Öğrencilerinin Sosyal Bilgiler Dersinin İşlenişine Yönelik Önerilerine İlişkin Bulgular}

Tablo 10. Kaynaştırma Öğrencilerinin Sosyal Bilgiler Dersinin İşlenişine Yönelik Önerileri

\begin{tabular}{ll}
\hline Öneriler & f \\
\hline Görsel & 4 \\
\hline Eğlenceli & 3 \\
\hline
\end{tabular}




\begin{tabular}{ll}
\hline Sessiz bir ders & 3 \\
\hline Gezi yaparak & 2 \\
\hline Oyunlar oynayarak & 2 \\
\hline Film ve videolu & 2 \\
\hline Canlandırmalar yaparak & 2 \\
\hline Beni uçuracak şekilde konular olmalı & 1 \\
\hline Tabletten & 1 \\
\hline
\end{tabular}

Tablo 10'a göre kaynaştırma öğrencilerinin sosyal bilgiler dersinin işlenişine yönelik önerileri incelendiğinde dersin daha çok aktif öğrenmeye uygun, etkileşimli, eğlenceli olmasını bekledikleri görülmektedir. Bununla birlikte öğrenciler kendileri için özel bir düzenleme önermememişlerdir. Öğrencilerden bazılarının önerileri şu şekildedir:

Sıkıcı olmayan, ĕglenceli bir ders olmalı. (Ö1).

Sessiz bir ortam olurda ders daha anlaşılır olur. (Ö10).

Beni uçuracak şekilde konular ilginç olmalı. (Ö8).

Ders oyunlar oynayarak, canlandırmalar yaparak işlenmeli. (Ö14).

\section{SONUÇ, TARTIŞMA ve ÖNERILLER}

Araştırmanın sonuçları genel olarak değerlendirildiğinde kaynaştırma öğrencilerinin sosyal bilgiler dersine, öğretmene, sosyal bilgiler öğretmenine yönelik olumlu metaforlar geliştirdikleri görülmektedir. Kaynaştırma öğrencileri sosyal bilgiler dersini daha çok tarih disiplini ile ilişskilendirmektedir. Araştırmada ayrıca sosyal bilgiler dersinin öğretmen merkezli işlenmekte olduğunu belirttikleri; öğrencilerin ise dersin daha aktif şekilde, oyunlaştırılarak, görsel unsurlara yer verilerek eğlenceli şekilde işlenmesini önerdikleri tespit edilmiştir.

Öğrencilerin derse yönelik metaforları genel olarak değerlendirildiğinde sosyal bilgiler dersi ile ilgili olumlu metaforlara ulaşıldığı söylenebilir. Kaynaştırma öğrencilerinin sosyal bilgiler dersine yönelik görüşleri ile ilgili literatür incelendiğinde Topçu ve Katılmış (2013), Büyükalan ve Yaylacı (2018) ile Yaşar ve Bayır (2010) tarafından yapılan çalışmalarda da kaynaştırma öğrencilerinin sosyal bilgiler dersine yönelik olumlu metaforlar ortaya koydukları görülmektedir.

Araştırmada kaynaştırma öğrencilerinin öğretmenlere yönelik metaforlarında en çok öğretmenin bilgi verici özelliğine vurgu yapıldığ görülmüştür. $\mathrm{Bu}$ durumun öğrencilerin öğretmenleri daha çok öğretici olarak görmeleri şeklinde yorumlanabilir. Yine araştırmada kaynaştırma öğrencilerinin sosyal bilgiler öğretmenine yönelik metaforlarının "bilgisayar, anne" gibi bilgi kaynağı ve şefkat unsurları çevresinde yoğunlaştığı görülmektedir. Öğrencilerin genel olarak sosyal bilgiler öğretmeni ve diğer branş öğretmenlerine karşı olumlu yönde görüş belirttiklerini söylemek mümkündür. Yenigün (2019) kaynaştırma öğrencileri üzerine yaptığ 1 çalışmada kaynaştırma eğitimi gören öğrencilerin matematik öğretmenini sevmelerinin öğrencilerin derse karşı ilgilerini arttırdığını ortaya koymuştur. Sabah, Taşmektepligil, Tunç, Ermiş ve Çavuşoğlu (2020) özel gereksinimli öğrencilerin beden eğitimi dersinde öğretmenlerinin kendileri için özel bir eğitim uygulamadığını ama kendilerine karşı 
olumlu tutum sergilediklerini, materyallerinin yeterli olduğunu ve arkadaşlarıyla olan ilişkilerinin olumlu olduğunu ifade etmiştir. Polat (2016)'ın çalışmasında ise özel gereksinimli öğrencilerin beden eğitimi dersinde öğretmenlerinin kendilerine kızmaması gerektiğini, onlara karşı daha nazik davranmalarını ve bireysel ihtiyaçlarına cevap verecek şekilde dersin işlenilmesi gerektiği yönünde görüşlerini belirttikleri görülmektedir. $\mathrm{Bu}$ sonuçlar doğrultusunda kaynaştırma öğrencilerinin, genel olarak sosyal bilgiler ve diğer branş öğretmenlerine yönelik olumlu görüşlere sahip oldukları söylenebilir.

Araştırmada kaynaştırma öğrencilerinin sosyal bilgiler dersini ağırlıklı olarak tarih disiplini ile bağdaşlaştırdıkları, daha sonra coğrafya ve diğer disiplinler ile ilişki kurdukları görülmüştür. Benzer şekilde Büyükalan ve Yaylacı (2018)'nın çalışmasında kaynaştırma ve normal gelişim gösteren öğrencilerin sosyal bilgiler dersi metaforlarının "tarih, geçmiş, tarihi eser ve müze" odaklı olduğu görülmektedir. Topçu ve Katılmış (2013) ise yarı zamanlı kaynaştırma öğrencilerinin sosyal bilgiler dersinde daha çok günlük yaşama transfer edebildikleri konuları öğrendiklerini belirtmişlerdir.

Araştırmada kaynaştırma öğrencilerinin sosyal bilgiler dersinin işlenişine yönelik düşünceleri incelendiğinde, dersin akıllı tahta ve kitap ağırlıklı öğretmen merkezli olarak işlendiğini belirttikleri görülmüştür. Bu doğrultuda kaynaştırma öğrencilerinin sosyal bilgiler dersinin işlenişine yönelik önerileri incelendiğinde öğrencilerin en çok derste görselliğe ağır verilmesini önerdikleri, dersin eğlenceli, sessiz bir ders, gezi yaparak, oyunlar oynayarak, film ve videolu, canlandırmalar yaparak işlenmesi yönünde önerilerde bulundukları tespit edilmiştir. İlgili literatür incelendiğinde sosyal bilgiler dersinin işlenişine yönelik benzer önerilere yer verilen çalışmalara rastlanmaktadır. Topçu ve Katılmış (2013)'ın araştırmasında kaynaştırma öğrencilerinin sosyal bilgiler dersinde oyun oynayarak, fiziksel aktivitelere katılarak daha aktif oldukları şekilde ders işlemeyi istedikleri sonucu ortaya konmuştır. Ayva (2010) çalışmasında, 4. sınıf normal gelişim gösteren öğrencilerin sosyal bilgiler dersinde aktif öğrenme uygulamalarını olumlu bulduklarını, öğrencilerin ders işlenirken çalışma kağıtları, görsel etkinlikler, okul gezileri ve proje ödevleri gibi uygulamalara yer verilmesini istediklerini belirtmiştir. Aykaç (2008) sosyal bilgiler dersini öğrencilerin daha iyi anlamaları ve sevmeleri için öğretmenlerin farklı yöntemler kullanmaları gerektiğini bunlardan birinin de yaratıcı drama yöntemi olduğunu belirtmiştir. Araştırmanın bu sonucundan ve ilgili literatürden hareketle sosyal bilgiler dersinin kaynaştırma öğrencilerine yönelik zengin bir içerikle işlenebilmesi için sosyal bilgiler öğretmenlerinin, lisans eğitiminden itibaren özel eğitim ihityacı olan biraylere yönelik etkinlik geliştirilmesi hususunda donanımlı hale getirilmeleri gerektiği söylenebilir.

Kaynaştırma öğrencilerinin sosyal bilgiler dersine yönelik sahip oldukları olumlu görüşlerin, akademik başarılarına da olumlu şekilde yansıması için öğretmenlere düşen görev büyüktür. $\mathrm{Bu}$ noktada her öğrencinin gelişim özelliğine ve engel durumuna dikkat ederek hazırlanacak olan BEP'lerin içerik açısından zenginleştirilmesi ve uygulanmasında da titizlik gösterilmelidir. Araştırmada öğrencilerin sosyal bilgileri daha çok tarih ile ilişkilendirdikleri ve derslerin eğlenceli şekilde işlenmesini önerdikleri görülmüştür. Bu sonuç doğrultusunda, öğretmenlerin öğrencilerin gelişim özelliklerine ve engel durumlarına uyarlanabilecek, sosyal bilgilerin displinlerarası yapısını kavratmayı hedefleyen eğlenceli içeriklerle BEP planlarını zenginleştirmeleri önerilebilir.

\section{KAYNAKÇA}

Akhan, N.E. \& Ateş, R.C. (2019). Sosyal bilgiler öğretmen adaylarının kaynaştırma eğitimine yönelik öz yeterlik inançlarının incelenmesi. Turkish Studies, (14), 3, 215-232. 
Akhan, N. E. \& Sönmez, N. (2018). Sosyal bilgiler öğretmenlerinin özel eğitim öğrencilerine yönelik özel alan yeterlilikleri. M. Yiğitoğlu (Ed.), I. Uluslararası Insan ve Toplum Bilimleri Araştırmaları Kongresi bildiri kitabı içinde (s.832-849). 23-25 Kasım, Antalya.

Aykaç, M. (2008). Sosyal bilgiler dersinde yaratıcı dramanın yöntem olarak kullanılmasının ögrenci başarısına etkisi. (Yayımlanmamış yüksek lisans tezi). Ankara Üniversitesi, Ankara.

Ayva, Ö. (2010). Sosyal bilgiler dersi öğrenme öğretme süreci ile ilgili öğrenci görüşleri. International Conference on New Trends in Education and Their Implications, 11(13), 276-282.

Berkeley, S., Marshak, L., Mastropieri, M.A. \& Scruggs, T.E. (2011). Improving student comprehension of social studies text: a self-questioning strategy for inclusive middle school classes. Remedial and Special Education 32(2) 105-113. Erişim adresi: https://doi.org/10.1177/0741932510361261

Büyükalan, S. \& Yaylac1, Z. (2018). Normal gelişim gösteren öğrenciler ile kaynaştırma öğrencilerinin sosyal bilgiler kavramına ilişkin metafor algıları. Ankara Üniversitesi Eğitim Bilimleri Fakültesi Özel Eğitim Dergisi, 8(4), 679-697.

Demirezen, S. \& Akhan, N. E. (2016). Sosyal bilgiler öğretmenlerinin kaynaştırma uygulamalarına ilişkin görüşleri. Abant İzzet Baysal Üniversitesi Eğitim Fakültesi Dergisi (USBES Özel Sayı II), 16, 1206-1223.

Diken, İ. H. \& Sucuoğlu, B. (1999). Sınıfında zihin engelli çocuk bulunan ve bulunmayan sınıf öğretmenlerinin zihin engelli çocukların kaynaştırılmasına yönelik tutumlarının karşılaştırılması. Özel Eğitim Dergisi, 2 (3), 25-39.

Gargia, J \& Michaelis, J.U. (1988). Social studies for children a guide to basic instructions. New Jersey: Prentice-Hall.

Görmez, E. (2016). Kaynaştırma öğrencilerinin sosyal bilgiler dersine yönelik performans düzeyleri. Mustafa Kemal Üniversitesi Sosyal Bilimler Enstitüsü Dergisi, 13(35), 144158.

İlk, G \& Açıkalın, M. (2018). Sosyal bilgiler öğretmenlerinin kaynaştirma uygulamalarina yönelik görüşlerinin ve deneyimlerinin incelenmesi. Milli Eğitim Dergisi, 209, 57-88.

Kargın, T. (2004). Kaynaştırma: tanımı, gelişimi ve ilkeleri. Ankara Üniversitesi Ĕ̆itim Bilimleri Fakültesi Dergisi, 5(2), 1-18.

Kaya, Ö. (2014). Özel eğitimde roller ve sorumluluklar. S. Vuran. (Ed.), Özel Ĕ̈itim (s. 3154). Ankara: Aya Akademi.

McFarland, J. (1998). Instructional ideas for social studies teachers of inclusion students. The Social Studies, 89(4), 150-153. Erişim adresi: http://dx.doi.org/10.1080/00377999809599842

MEB ÖRGM (Milli Eğitim Bakanlığı Özel Eğitim ve Rehberlik Danışma Hizmetleri Genel Müdürlüğü) (2010), Okullarımızda neden niçin nasıl kaynaştırma yönetici, ögretmen ve aile kılavuzu. Ankara.

MEB ÖRGM (Milli Eğitim Bakanlığı Özel Eğitim ve Rehberlik Danışma Hizmetleri Genel Müdürlügü) (2013). Bütünleştirme kapsamında eğitim uygulamaları ögretmen kılavuz kitabl. Ankara. 
MEB Özel Eğitim Hizmetleri Yönetmeliği. (2018). Resmi Gazete (Sayı: 30471). Erişim adresi: http://www.resmigazete.gov.tr/eskiler/2018/07/20180707-8.htm

Miles, M. B. \& Huberman, A.M. (1994). Qualitative data analysis: An expanded sourcebook. (2nd Edition). Calif.: SAGE Publications.

Ochoa, A.S. \& Shuster, S.K. (1980). Social studies in the mainstreamed classroom, K-6. Boulder, CO: Social Science Education Consortium.

Polat, R. (2016). Ortaokul öğrencisi olan kaynaştirma öğrencilerinin beden ĕgitimi dersine yönelik görüşleri. (Yayımlanmamış yüksek lisans tezi). Marmara Üniversitesi. İstanbul.

Sabah, S., Taşmektepligil, M.Y., Tunç, T., Ermiş, A. \& Çavuşoğlu, G. (2020). Kaynaştırma öğrencilerinin beden eğitimi dersine yönelik görüş ve gereksinimlerinin incelenmesi. Beden Eğitimi ve Spor Bilimleri Dergisi, 18(1), 81-95.

Sharma, U., Forlin, C \& Loreman, T. (2008). Impact of training on pre-service teachers' attitudes and concerns about inclusive education and sentiments about persons with disabilities, Disability \& Society, 23 (7), 773-785, Erişim adresi: https://doi.org/10.1080/09687590802469271

Topçu, E. \& Katılmış, A. (2013). Yarı zamanlı kaynaştırma eğitimi alan ortaokul öğrencilerinin sosyal bilgiler dersine yönelik düşünceleri, Sakarya University Journal of Education, 3(3), 48-81.

Troy, J.J. \& Busby, R. (2015). Including young learners with special needs in social studies classrooms. Social Studies Research and Practice, 10(3), 98-108.

TÜİK. (2010). Engellilerin sorun ve beklentileri araştırmast. Ankara.

TÜİK. (2011). Nüfus ve konu araştırması. Ankara. Erişim adresi:

https://ailevecalisma.gov.tr/media/5677/nufus-ve-konut-arastirmasi-engellilikarastirmasonuclari.pdf

Urban, D.J. (2013). Toward a framework of inclusive social studies: obstacles and opportunities in a preservice teacher education program. (Master thesis). Columbia University. ProQuest Dissertations Publishing, 3561042.

Yaşar, Ş. \& Bayır, Ö.M. (2010). İlköğretim 5. sınıf öğrencilerinin bakış açisiyla sosyal bilgiler. Education Sciences, 5(3), 1213-1225.

Yaylac1, Z \& Aksoy, B. (2016). Sosyal bilgiler öğretmenlerinin kaynaştırma eğitimindeki yeterlilikleri. Uluslararası Türk Eğitim Bilimleri Dergisi, 4(6), 19-40.

Yenigün, E. (2019). Ortaokulda kaynaştırma eğitimi görmekte olan öğrencilerin matematik dersine ilişkin görüşleri. 2 nd International Congress on New Horizons in Education and Social Sciences (ICES-2019), June 18-19, 2019, Istanbul-TURKEY, Proceedings Book, pp. 368-373.

Yıldırım, A. \& Şimşek, H. (2006). Sosyal bilimlerde nitel araştırma yöntemleri. Ankara: Seçkin Yayınları.

Yıldırım, S. (2019). Sosyal bilgiler öğretmenlerinin kaynaştırma eğitimine ilişkin yeterlilikleri: Samsun ili örneği. (Yayımlanmamış yüksek lisans tezi). Ondokuz Mayıs Üniversitesi, Samsun.

Young Buckley, C. (2005), Establishing and maintaining collaborative relationships between regular and special education teachers in middle school social studies inclusive 
classrooms, Scruggs, T.E. and Mastropieri, M.A. (Ed.) Cognition and Learning in Diverse Settings (Advances in Learning and Behavioral Disabilities, Vol. 18), Emerald Group Publishing Limited, Bingley, pp. 153-198. Erişim adresi: https://doi.org/10.1016/S0735-004X(05)18008-2

World Health Organization (WHO) (2011). World report on disability. Malta: WHO Press. Erişim adresi: https://www.who.int/disabilities/world_report/2011/report/en/ 